\title{
Quantitative Microbial Risk Assessment for Campylobacter spp. on Ham in Korea
}

\author{
Jeeyeon Lee, Jimyeong Ha, Sejeong Kim, Heeyoung Lee, Soomin Lee, and Yohan Yoon* \\ Department of Food and Nutrition, Sookmyung Women's University, Seoul 04310, Korea
}

\begin{abstract}
The objective of this study was to evaluate the risk of illness from Campylobacter spp. on ham. To identify the hazards of Campylobacter spp. on ham, the general characteristics and microbial criteria for Campylobacter spp., and campylobacteriosis outbreaks were investigated. In the exposure assessment, the prevalence of Campylobacter spp. on ham was evaluated, and the probabilistic distributions for the temperature of ham surfaces in retail markets and home refrigerators were prepared. In addition, the raw data from the Korea National Health and Nutrition Examination Survey (KNHNES) 2012 were used to estimate the consumption amount and frequency of ham. In the hazard characterization, the Beta-Poisson model for Campylobacter spp. infection was used. For risk characterization, a simulation model was developed using the collected data, and the risk of Campylobacter spp. on ham was estimated with@RISK. The Campylobacter spp. cell counts on ham samples were below the detection limit $(<0.70 \mathrm{Log}$ CFU/g). The daily consumption of ham was $23.93 \mathrm{~g}$ per person, and the consumption frequency was $11.57 \%$. The simulated mean value of the initial contamination level of Campylobacter spp. on ham was $-3.95 \mathrm{Log} \mathrm{CFU} / \mathrm{g}$, and the mean value of ham for probable risk per person per day was $2.20 \times 10^{-12}$. It is considered that the risk of foodborne illness for Campylobacter spp. was low. Furthermore, these results indicate that the microbial risk assessment of Campylobacter spp. in this study should be useful in providing scientific evidence to set up the criteria of Campylobacter spp..
\end{abstract}

Keywords: Campylobacter spp., ham, quantitative microbial risk assessment

Received June 10, 2015; Revised September 16, 2015; Accepted September 17, 2015

\section{Introduction}

Foodborne illness caused by meat and processed meat products occurs steadily worldwide (Pépin et al., 1997). In particular, the consumption of meat is increasing due to the fact that the grain-oriented diet has been converted to a meat-oriented diet in Korea (KREI, 2012). According to the Korea National Health and Nutrition Examination Survey 2012, the intake of meat has increased from 67.8 $\mathrm{g}$ in 1997 to $113.8 \mathrm{~g}$ in 2012 (MHW, 2012). In addition, the consumption of fermented-cured ham, which is consumed without further processing such as cooking or heating, has been increased. The increased intake of meat and processed meat products may cause increased foodborne outbreaks related to animal products (MFDS, 2013a).

The most common pathogenic microorganisms in meat

\footnotetext{
*Corresponding author: Yohan Yoon, Department of Food and Nutrition, Sookmyung Women's University, Seoul 04310, Korea. Tel: +82-2-2077-7585, Fax: +82-2-710-9479, E-mail: yyoon@ sookmyung.ac.kr
}

and processed meat products are Campylobacter spp., Clostridium perfringens, Salmonella spp., Escherichia coli O157:H7, and Listeria monocytogenes (Borch and Arinder, 2002). Among these, Campylobacter spp. has been recognized as a foodborne illness bacterium related to livestock (Doyle and Erickson, 2006). Campylobacter spp. can survive well in fresh poultry, pork, beef, other processed meat products, and dairy products (JacobsReitsma, 2000; Sammarco et al., 2010; Taremi et al., 2006; Wong et al., 2007).

Campylobacter jejuni and Campylobacter coli are the major species of Campylobacter spp. (Ge et al., 2013), and they cause sporadic gastrointestinal infection (Blaser, 1997; Gormley et al., 2008). In particular, C. jejuni became the cause of approximately $90 \%$ of acute gastroenteritis cases (Park, 2001). In the United States, C. jejuni is the main pathogenic bacterium responsible for diarrhea, and foodborne illness caused by Campylobacter spp. is more frequent than foodborne illness caused by Salmonella spp. and E. coli O157:H7 (USDA, 2010). Also, human campylobacteriosis in Japan has been reported more than 2,000 cases per year since 2001 (Haruna et al., 2012).

(9)This is an open access article distributed under the terms of the Creative Commons Attribution Non-Commercial License (http://creativecommons.org/licences/ by-nc/3.0) which permits unrestricted non-commercial use, distribution, and reproduction in any medium, provided the original wokr is properly cited. 
Kubota et al. (2008) showed that estimated patients for campylobacteriosis in Japan might be 241,925 persons in 2005. In Korea, foodborne outbreaks related to $C$. jejuni were 13 cases (329 hospitalizations) in 2011 (MFDS, 2014).

Microbial risk assessment (MRA) is one of the scientific methods to evaluate the risk levels of microbial risk factors. MRA is composed of four stages such as hazard identification, exposure assessment, hazard characterization and risk characterization (CAC, 1999). In hazard identification, the level of potential hazards for microorganism is defined (Notermans and Teunis, 1996). For exposure assessment, the possible populations of microorganism are estimated at the point of consuming certain foods (Lammerding and Fazil, 2000; Notermans and Teunis, 1996). The populations of contamination, growth or death of microorganisms, consumed pattern of foods and cross-contamination are examined through the food distribution process. Dose response models are used in hazard characterization, and the risk of microorganism is calculated by the data from exposure assessment and hazard characterization for risk characterization (Notermans and Teunis, 1996). Then, microbiological criteria may be established by the result of MRA.

Even though foodborne illness of Campylobacter spp. by food consumption has been increasing in Korea, microbiological criteria for the pathogens are not well-established for each food. Therefore, the objective of this study was to evaluate the microbial risk of Campylobacter spp. on ham in Korea and present a scientific basis for the criteria.

\section{Materials and Methods}

\section{Hazard identification}

To identify the hazards of Campylobacter spp., the general characteristics, microbial criteria for Campylobacter spp., and outbreaks of foodborne illness for consumption of Campylobacter spp. were investigated by literatures.

\section{Exposure assessment}

\section{Prevalence}

To evaluate the prevalence and contamination levels of Campylobacter spp., pressed hams with antimicrobials (ham $\mathrm{A}, \mathrm{N}=80$ ), pressed hams without antimicrobials (ham $\mathrm{B}, \mathrm{N}=80$ ), and fermented-cured hams (ham $\mathrm{C}, \mathrm{N}=40$ ) were purchased from local grocery stores in Seoul and from a manufacturer in Hongseong, S. Korea. Twenty five-gram portions of the samples were aseptically transferred to a sterilized bag. A hundred milliliter Bolton broth (Oxoid Ltd., UK), formulated with laked-horse blood, was added to the bag, and homogenized in a pummeler (BagMixer ${ }^{\circledR}$, Interscience, St. Nom) for $90 \mathrm{~s}$.

The homogenates were incubated for $5 \mathrm{~h}$ at $37^{\circ} \mathrm{C}$ for the first enrichment, followed by incubation at $42^{\circ} \mathrm{C}$ for $44 \mathrm{~h}$ for the second enrichment in a microaerobic environment. The cultures were then streaked onto Campylobacter blood-free selective agar plates (modified CCDAPreston, mCCDA; Oxoid Ltd.) and incubated microaerobically at $42^{\circ} \mathrm{C}$ for $48 \mathrm{~h}$. Following incubation, one presumptive Campylobacter spp. colony was streaked onto two Colombia agar plates (bioMérieux, Marcy-l'Étoile) and incubated at $42^{\circ} \mathrm{C}$ for $48 \mathrm{~h}$ in the aerobic and microaerobic conditions, respectively. When colonies appeared only in the microaerobic environment, these were further analyzed to identify Campylobacter spp., using the PCR method described by Yamazaki-Matsune et al. (2007). One-milliliter portions of the homogenates were also surface-plated onto mCCDA (Oxoid Ltd.) to enumerate Campylobacter spp. cell counts, and the plates were incubated at $42^{\circ} \mathrm{C}$ for $48 \mathrm{~h}$ under microaerobic conditions. Following incubation, all presumptive Campylobacter spp. colonies were counted. Five randomly selected colonies of presumptive Campylobacter spp. were analyzed to identify Campylobacter spp., using the method described above. To obtain Campylobacter spp. cell counts, the ratio of identified Campylobacter spp. was multiplied by the number of presumptive Campylobacter spp. colonies.

Initial contamination level and Campylobacter spp. fate

The prevalence data (PR) of Campylobacter spp. was fitted to a beta distribution ( $\alpha_{1}$, the number of positive samples $+1 ; \alpha_{2}$, tested total samples-positive samples +1 ), and the contamination level $(\mathrm{CFU} / \mathrm{g})$ was calculated using the equation: [-LN(1-PR)/weight] (Sanaa et al., 2004; Vose, 1998) to estimate the initial contamination level. During the distribution and storage, the growth or death of Campylobacter spp. cells were estimated by a predictive model developed by González et al. (2009) (Table 1).

\section{Temperature for distribution and storage}

To simulate the storage environment, the temperatures were measured with an non contact infrared thermometer (HS-33CT, Hansung, Seoul) at eight retail markets, and results from the MFDS (2013b) were used for home refrigerator temperature profiles. 
Table 1. Predictive model for Campylobacter spp. developed by González et al. (2009) to estimate the $\delta$ and p values

\begin{tabular}{ccccc}
\hline \hline & & & \\
& $\delta(\mathrm{T})=10^{\mathrm{AT}^{3}+\mathrm{BT}^{2}+\mathrm{CT}+\mathrm{D}}$ & $\mathrm{R}^{2}$ & \\
\hline $\mathrm{A}$ & $\mathrm{B}$ & $\mathrm{C}$ & $\mathrm{D}$ & 0.963 \\
\hline$-6 \times 10^{-5}$ & $-7 \times 10^{-4}$ & $2.97 \times 10^{-2}$ & \\
\hline $\mathrm{E}$ & $\mathrm{p}(\mathrm{T})=10^{\mathrm{ET}^{3}+\mathrm{FT}^{2}+\mathrm{GT}+\mathrm{H}}$ & & $\mathrm{R}^{2}$ \\
\hline $2 \times 10^{-5}$ & $\mathrm{G}$ & $\mathrm{H}$ & -0.15 & 0.880 \\
\hline
\end{tabular}

Consumption of ham in Korea

To obtain the amounts of ham consumption in Korea, 24-h recall data from the Korea National Health and Nutrition Examination Survey (KNHNES) 2012 were analyzed by the $\mathrm{SAS}^{\circledR}$ program version 9.3 (SAS Institute
Inc., USA). Each data was then fitted to the @RISK program version 6 (Palisade Corp., Ithaca) to obtain appropriate data distributions. To estimate the consumption frequencies for ham, the number of people who consumed ham was divided into the total respondents.

Table 2. Simulation model and formulas in Excel ${ }^{\circledR}$ spreadsheet used to calculate the risk of Campylobacter spp. on ham with (a)RISK

\begin{tabular}{|c|c|c|c|c|}
\hline Input Model & Unit & Variable & Formula & References \\
\hline \multicolumn{5}{|l|}{ PRODUCT } \\
\hline \multicolumn{5}{|l|}{$\begin{array}{l}\text { Pathogens } \\
\text { contamination level }\end{array}$} \\
\hline Campylobacter prevalence & & PR & $=\operatorname{RiskBeta}(1,201)$ & Vose (1998) \\
\hline \multirow[t]{2}{*}{ Initial contamination level } & $\mathrm{CFU} / \mathrm{g}$ & $\mathrm{C}_{\mathrm{i}}$ & $=-\mathrm{LN}(1-\mathrm{PR}) / 25 \mathrm{~g}$ & Sanaa et al. (2004) \\
\hline & Log CFU/g & IC & $=\log \left(C_{i}\right)$ & \\
\hline \multicolumn{5}{|l|}{ MARKET } \\
\hline \multicolumn{5}{|l|}{ Market storage } \\
\hline Storage time & $\mathrm{h}$ & Mark-time $_{\text {st }}$ & $=\operatorname{RiskPert}(0,1.5,3)$ & Personal communication \\
\hline $\begin{array}{l}\text { Food temperature } \\
\text { during storage }\end{array}$ & ${ }^{\circ} \mathrm{C}$ & Mark-Temp $p_{\text {st }}$ & $=$ RiskUniform $(0,10)$ & Personal communication \\
\hline \multicolumn{5}{|l|}{ Growth } \\
\hline delta & & delta & $=10^{\left(2.97 \times 10^{-2} \times \text { Mark-Temp }\right.}{ }^{\left\{\left(-6 \times 10^{-5} \times \text { Mark }- \text { Temp }_{\mathrm{st}}{ }^{3}\right)+1.07\right\}}$ & González et al. (2009) \\
\hline $\mathrm{p}$ & & $\mathrm{p}$ & $=10^{\left(-1.1 \times 10^{-3} \times \text { Mark-Temp }\right.} \begin{array}{c}\left\{\left(2 \times 10^{-5} \times \text { Mark }\right)^{-}-0.15\right\} \\
\left(-5 \times 10^{-4} \times \text { Mark }_{\text {st }}{ }^{3}\right)+\end{array}$ & González et al. (2009) \\
\hline $\begin{array}{l}\text { Campylobacter } \\
\text { growth model }\end{array}$ & Log CFU/g & $\mathrm{C} 1$ & $=\mathrm{IC}-\left(\text { Mark-time } \mathrm{st}_{\mathrm{st}} / \mathrm{delta}\right)^{\mathrm{p}}$ & Mafart et al. (2002) \\
\hline \multicolumn{5}{|l|}{ Market display } \\
\hline Storage time & $\mathrm{h}$ & Mark-time $_{\text {dis }}$ & $=\operatorname{RiskPert}(0,72,120)$ & Personal communication \\
\hline $\begin{array}{l}\text { Food temperature } \\
\text { during storage }\end{array}$ & ${ }^{\circ} \mathrm{C}$ & Mark-Temp $p_{\text {dis }}$ & $\begin{aligned}= & \text { RiskBetaGeneral }(2.1385,2.4086,3.2875 \text {, } \\
& 12.9912)\end{aligned}$ & This research \\
\hline \multicolumn{5}{|l|}{ Growth } \\
\hline delta & & delta & 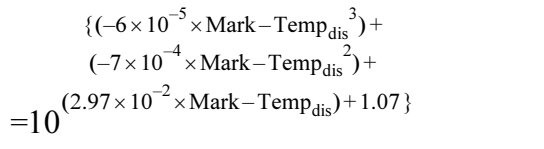 & González et al. (2009) \\
\hline $\mathrm{p}$ & & $\mathrm{p}$ & 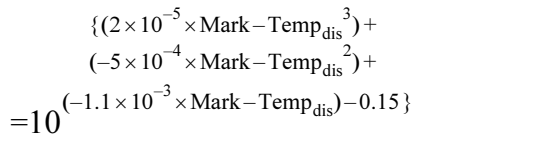 & González et al. (2009) \\
\hline $\begin{array}{l}\text { Campylobacter } \\
\text { growth model }\end{array}$ & Log CFU/g & $\mathrm{C} 2$ & $=\mathrm{C} 1-\left(\text { Mark-time } \mathrm{dis}_{\mathrm{dis}} / \mathrm{delta}\right)^{\mathrm{p}}$ & Mafart et al. (2002) \\
\hline
\end{tabular}


Table 2. Simulation model and formulas in Excel $^{\circledR}$ spreadsheet used to calculate the risk of Campylobacter spp. on ham with (a)RISK (Continued)

\begin{tabular}{|c|c|c|c|c|}
\hline Input Model & Unit & Variable & Formula & References \\
\hline \multicolumn{5}{|c|}{ TRANSPORTATION (CAR) } \\
\hline \multicolumn{5}{|c|}{$\begin{array}{l}\text { Transportation (car) } \\
\text { storage }\end{array}$} \\
\hline Transportation time & $\mathrm{h}$ & Trans-time $_{\text {car }}$ & $=\operatorname{RiskPert}(0.325,0.984,1.643)$ & Jung (2011) \\
\hline $\begin{array}{l}\text { Food temperature } \\
\text { during transportation }\end{array}$ & ${ }^{\circ} \mathrm{C}$ & Trans-Temp $p_{\text {car }}$ & $=\operatorname{RiskPert}(10,18,25)$ & Jung (2011) \\
\hline \multicolumn{5}{|l|}{ Growth } \\
\hline delta & & delta & 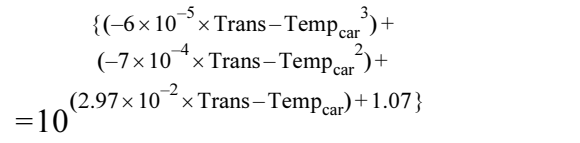 & González et al. (2009) \\
\hline $\mathrm{p}$ & & $\mathrm{p}$ & 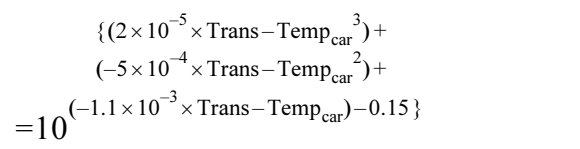 & González et al. (2009) \\
\hline $\begin{array}{l}\text { Campylobacter } \\
\text { growth model }\end{array}$ & Log CFU/g & $\mathrm{C} 3$ & $=\mathrm{C} 2-\left(\text { Trans-time } \mathrm{car}_{\mathrm{ar}} / \mathrm{delta}\right)^{\mathrm{p}}$ & Mafart et al. (2002) \\
\hline \multicolumn{5}{|l|}{ HOME } \\
\hline \multicolumn{5}{|l|}{ Home storage } \\
\hline Storage time & $\mathrm{h}$ & Home-time $_{\text {st }}$ & $=\operatorname{RiskPert}(0,168,504)$ & Personal communication \\
\hline $\begin{array}{l}\text { Food temperature } \\
\text { during storage }\end{array}$ & ${ }^{\circ} \mathrm{C}$ & Home-Temp $_{\text {st }}$ & $=$ RiskLogLogistic(-29.283, 33.227, 26.666) & MFDS (2013b) \\
\hline \multicolumn{5}{|l|}{ Growth } \\
\hline delta & & delta & $=10^{\left.\left(2.97 \times 10^{-2} \times \text { Home }- \text { Temp }_{\mathrm{st}}\right)+1.07\right\}} \begin{array}{c}\left\{\left(-6 \times 10^{-5} \times \text { Home }- \text { Temp }_{\mathrm{st}}{ }^{3}\right)+\right. \\
\left(-7 \times 10^{-4} \times \text { Home }-\mathrm{Temp}_{\mathrm{st}}{ }^{2}\right)+\end{array}$ & González et al. (2009) \\
\hline $\mathrm{p}$ & & $\mathrm{p}$ & $=10^{\left.\left(-1.1 \times 10^{-3} \times \text { Home }- \text { Temp }_{\text {st }}\right)-0.15\right\}} \begin{array}{c}\left\{\left(2 \times 10^{-5} \times \text { Home }- \text { Temp }_{\text {st }}{ }^{3}\right)+\right. \\
\left(-5 \times 10^{-4} \times \text { Home }^{2}{ }^{2}+\right.\end{array}$ & González et al. (2009) \\
\hline $\begin{array}{l}\text { Campylobacter } \\
\text { growth model }\end{array}$ & $\mathrm{Log}$ CFU/g & $\mathrm{C} 4$ & $=\mathrm{C} 3-\left(\text { Home-time }_{\mathrm{st}} / \mathrm{delta}\right)^{\mathrm{p}}$ & Mafart et al. (2002) \\
\hline \multicolumn{5}{|l|}{ CONSUMPTION } \\
\hline $\begin{array}{l}\text { Daily consumption } \\
\text { average amount }\end{array}$ & $\mathrm{g}$ & Consump & $\begin{aligned}= & \operatorname{RiskLogLogistic}(0.032518,11.282, \\
& 1.4216, \text { RiskTruncate }(0,1000))\end{aligned}$ & MHW (2012) \\
\hline \multirow[t]{5}{*}{$\begin{array}{l}\text { Daily consumption } \\
\text { frequency }\end{array}$} & $\%$ & ConFre & Fixed 11.57 & MHW (2012) \\
\hline & & $\mathrm{CF}(0)$ & $=1-11.57 / 100$ & MHW (2012) \\
\hline & & $\mathrm{CF}(1)$ & $=11.57 / 100$ & MHW (2012) \\
\hline & & $\mathrm{CF}$ & $=\operatorname{RiskDiscrete}(\{0,1\},\{\mathrm{CF}(0), \mathrm{CF}(1)\})$ & MHW (2012) \\
\hline & & Amount & $=\mathrm{IF}(\mathrm{CF}=0,0$, Consump $)$ & MHW (2012) \\
\hline \multicolumn{5}{|l|}{ DOSE-RESPONSE } \\
\hline Campylobacter amount & & $\mathrm{n}$ & $=10^{\mathrm{C} 4} \times$ Amount & \\
\hline \multirow[t]{3}{*}{ Parameter } & & $\alpha$ & Fixed 0.145 & Teunis and Havelaar (2000) \\
\hline & & $\beta$ & Fixed 7.59 & Teunis and Havelaar (2000) \\
\hline & & $\mathrm{p}_{1}$ & $=\operatorname{RiskBeta}(\alpha, \beta)$ & Teunis and Havelaar (2000) \\
\hline \multicolumn{5}{|l|}{ RISK } \\
\hline Probability of infection & & $P_{i n f}(n)$ & $=1-\left(1-p_{1}\right)^{n}$ & Nauta et al. (2007) \\
\hline $\begin{array}{l}\text { Probability of illness } \\
\text { given infection }\end{array}$ & & $\mathrm{P}_{\text {ill } \mid \text { inf }}$ & Fixed 0.33 & Nauta et al. (2007) \\
\hline $\begin{array}{l}\text { Probability of illness/ } \\
\text { person/day }\end{array}$ & & Risk & $=P_{i n f}(n) \times P_{i l l i n f}$ & Nauta et al. (2007) \\
\hline
\end{tabular}




\section{Hazard characterization}

\section{Dose-response model}

To estimate the probability of illness per person per day from the consumption of Campylobacter cells, the BetaPoisson model for the dose-response of Campylobacter developed by Teunis and Havelaar (2000) was used. The probability of infection by consumed Campylobacter cells, $p_{1}$, is the value described by the beta distribution $\left[p_{1} \sim \operatorname{beta}(\alpha, \beta)\right]$. Subsequently, the probability of infection $\left(P_{i n f}\right)$ due to the consumption of Campylobacter cells (n) is described as $P_{i n f}(n)=1-\left(1-p_{1}\right)^{n}$. The probability of illness given infection $\left(P_{\text {ill }[i n f}\right)$ was assumed by another study (Nauta et al., 2007). Eventually, the probability of illness per person per day for Campylobacter spp. $\left(P_{i l l}(\mathrm{n})\right)$ can be calculated by multiplying $P_{i n f}(\mathrm{n})$ and $P_{\text {illinf }}$.

\section{Risk characterization}

To estimate the probability of illness per person per day due to the consumption of ham, a simulation model was developed in an Excel ${ }^{\circledR}$ (MicroSoft Excel 2007, MicroSoft Corp.) spreadsheet (Table 2) based on data for prevalence, contamination level, storage temperature distribution, consumption amounts and frequencies of ham, the dose-response model and the opinion of employees, and analyzed using the @RISK program with settings for 10,000 iterations.

\section{Results and Discussion}

\section{Hazard identification of Campylobacter spp.}

Campylobacter spp. are zoonotic bacteria for humans and animals. This bacterium is hard to detect and control because of its VBNC (viable but non-culturable) characteristics (Blackburn and McClure, 2009). The clinical symptoms by Campylobacter spp. are mainly fever, diarrhea, vomiting, Reiter syndrome, rarely Guillain-Bare syndrome, and severely death (Fugimotto et al., 1992). The minimum infectious doses are 400-500 CFU, and general infectious doses are 10,000 CFU (Heyndrickx et al., 2001; Luning et al., 2006; MFDS, 2012). Campylobacter spp. are usually isolated from fresh meat, especially poultry, and they can be cross-contaminated during food preparation, resulting in Campylobacter spp. foodborne illness (Nauta et al., 2007; Nauta et al., 2009). Cytolethal distending toxin (CDT) is the main toxin produced by Campylobacter spp., and the toxin prevents cell division and induces cell death (Yamasaki et al., 2006).

In Korea, the foodborne illness related to Campylobacter spp. resulted in 68 outbreaks and 2,858 cases in the last 10 years (MFDS, 2014). Although foodborne illness caused by Campylobacter spp. has been increased in Korea, a risk assessment for Campylobacter spp. has not been conducted. Thus, a microbial risk assessment for Campylobacter spp. is necessary.

\section{Initial contamination level of Campylobacter spp.}

To collect the prevalence data for Campylobacter spp., three types of ham were analyzed at the retail markets. For all samples $(\mathrm{n}=200)$, Campylobacter spp. cells were below the detection limit $(0.70 \mathrm{Log} \mathrm{CFU} / \mathrm{g})$. Hence, the initial contamination level of Campylobacter spp. was predicted by beta-distribution Vose (1998) and the equation developed by Sanaa et al. (2004). As a result, the mean

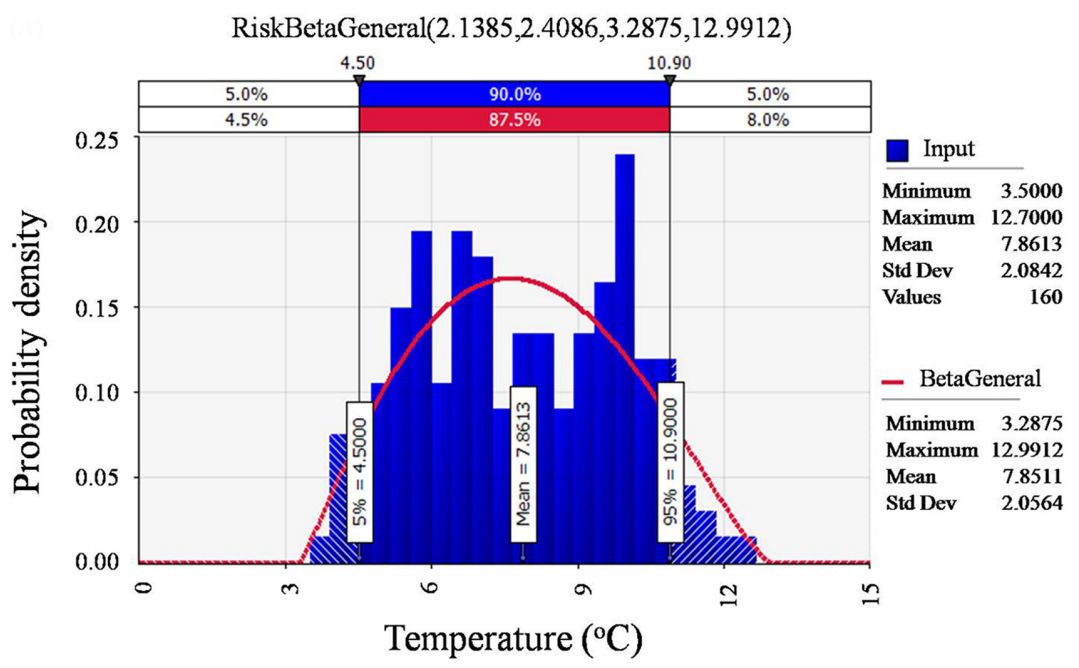

Fig. 1. Probabilistic distributions for temperature at retail markets with@RISK. 
value of initial contamination level of Campylobacter spp. on ham was 3.95 $\pm 0.56 \mathrm{Log} \mathrm{CFU} / \mathrm{g}$, calculated from the prevalence and contamination level of Campylobacter spp.. It was indicated that Campylobacter spp. were present at an average of $0.11 \mathrm{CFU}$ per $1 \mathrm{~kg}$ of ham. Therefore, the initial contamination level of Campylobacter spp. was very low.

Campylobacter spp. usually was found in poultry and other raw meats due to the fact that meats, especially poultry, are the main reservoirs of contamination of this bacterium (Nielsen et al., 2006). Campylobacter spp. were present in 94 out of 289 poultry samples (32.5\%) in Belgium in 2002 (Uyttendaele et al., 2006), and 16\% (almost C. jejuni) of 636 carcasses in Sweden (Lindblad et al., 2006). Also, 259 samples of total 1,011 raw meats (chicken, pork, unweaned veal, lamb, mutton, and beef samples) were contaminated with Campylobacter spp. (Wong et al., 2007). Compared to these results, it is considered that prevalence of Campylobacter spp. on ham was very low.

\section{Campylobacter spp. fate during display, storage and consumption of ham}

To evaluate the fate of Campylobacter spp. during the display, storage and consumption of ham, in the exposure assessment, a predictive model for Campylobacter spp. was referred to in a study by González et al. (2009). The results show that Campylobacter spp. cell counts decreased during the distribution process of ham such as display, grocery store storage and home storage. In addition, temperatures in surface of ham at display and storage were measured approximately 20 times, each for $30 \mathrm{~min}$, at eight retail markets. The mean of the temperature profile at retail was $7.39 \pm 1.96^{\circ} \mathrm{C}$, and the minimum and maximum temperatures were 3.5 and $12.7^{\circ} \mathrm{C}$, respectively. Collected temperature data from eight retail markets were fitted by@RISK, and its appropriate probabilistic distribution was 'BetaGeneral distribution (2.1385, 2.4086, $3.2875,12.9912$ )'. The mean, minimum and maximum values of the temperature were $7.85,3.29$ and $12.99^{\circ} \mathrm{C}$, respectively (Fig. 1). In home refrigerators, the mean temperature profile was $4.06 \pm 2.28^{\circ} \mathrm{C}$, and the minimum and maximum temperatures were 3.50 and $10.8^{\circ} \mathrm{C}$, respectively (MFDS, 2013a). The appropriate probabilistic distribution for home refrigerators was 'LogLogistic distribution $(-29.283,33.227,26.666)$ ', and the mean value was $4.02 \pm$ $2.27^{\circ} \mathrm{C}$.

\section{Ham consumption pattern in Korea}

The daily consumption amount of ham was extracted from the KNHNES 2012 using the $\mathrm{SAS}^{\circledR}$ version 9.3 and fitted by @RISK. The 'LogLogistic distribution ( 0.032518 , $11.282,1.4216$ )' was appropriate to explain the consumption amount of ham, and the mean value of the daily consumption of ham was $31.10 \mathrm{~g}$ per day (Fig. 2). The ratio of total respondents $(7,208$ people) and the respondents who consumed ham ( 834 people) was calculated to estimate the frequency of consumption, which was found to be $11.57 \%$. The Discrete distribution was used to estimate the consumption level of Campylobacter spp. per person per day.

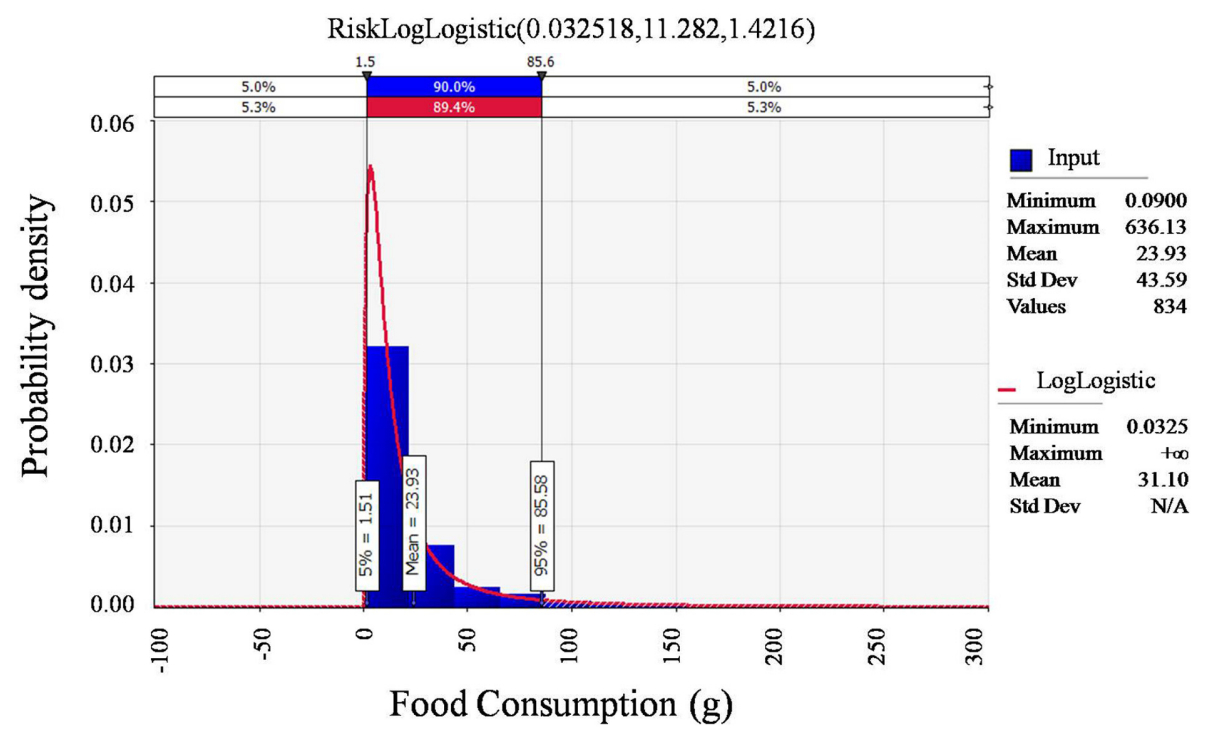

Fig. 2. Probabilistic distribution for ham intake in the Korea National Health and Nutrition Examination Survey (KNHNES) 2012 with@RISK. 
Table 3. Probability of foodborne illness by Campylobacter spp. per person per day with consumption of ham

\begin{tabular}{ccccccc}
\hline \hline Ham & $5 \%$ & $50 \%$ & $95 \%$ & $99 \%$ & Maximum & Mean \\
\hline Probability of illness/person/day & 0 & 0 & $6.23 \times 10^{-16}$ & $1.68 \times 10^{-12}$ & $7.96 \times 10^{-9}$ & $2.20 \times 10^{-12}$ \\
\hline
\end{tabular}

\section{Dose-response}

The values of $\alpha$ and $\beta$ in Campylobacter were 0.145 and 7.59, respectively, then $p_{1}$ was 0.019 , as the Beta distribution $\left[p_{1} \sim \operatorname{Beta}(\alpha, \beta)\right]$. According to other research (Nauta et al., 2007), $P_{\text {ill linf }}$ was 0.33 because 29 of 89 individuals who were infected developed the illness.

\section{Risk characterization}

To estimate the probability of illness per person per day caused by ham consumption, a simulation model was developed with the results listed above. The simulation model showed that Campylobacter spp. cell counts decreased during distribution and storage. The ingested dose of Campylobacter spp. by consumption of ham was estimated by final contamination level, consumption amount per day and frequency of consumption. The mean and maximum value of the probability of a Campylobacter spp. foodborne illness for ham per person per day were $2.20 \times$ $10^{-12}$ and $7.96 \times 10^{-9}$, respectively (Table 3 ). From these results it can be assumed that the mean and maximum values for the probability of Campylobacter spp. foodborne illness were $8.03 \times 10^{-10}$ and $2.91 \times 10^{-6}$ per person per year for ham. In other literature, the mean probabilities of campylobacteriosis ingested from a chicken meal were $3.1 \times 10^{-2}$ for children, and $1.5 \times 10^{-2}$ for adults in Dakar, Senegal (Pouillot et al., 2012). In addition, the mean probability of illness caused by E. coli $\mathrm{O} 157: \mathrm{H} 7$ was $5.1 \times 10^{-5}$ for adults and $3.7 \times 10^{-5}$ for children from the consumption of hamburgers (Cassin et al., 1998). Ross et al. (2009) showed that the predicted mean values for risk of listeriosis per serving for processed meats, pâtés, and cooked sausages were $1.00 \times 10^{-8}, 2.28 \times 10^{-9}$, and $7.06 \times 10^{-9}$, respectively. Compared with these studies, it is considered that the risk of Campylobacter spp. on ham is very low.

In the sensitivity analysis, the consumption amount of ham, dose-response model, prevalence of Campylobacter spp., and storage temperature at home were positive factors for the probable level of risk, while time for market display and transportation in a car were negative factors. According to these results, the temperature conditions were more important factor than time, to reduce the risk of foodborne illness caused by Campylobacter spp..

In conclusion, the risk of Campylobacter spp. through ham intake is very low in Korea. However, the control of foodborne illness caused by Campylobacter spp. on ham is necessary due to the fact that the consumption amount of ham has increased. In addition, the results indicate that the microbial risk assessment of Campylobacter spp. in this study should be useful in providing scientific evidence to set up the criteria of Campylobacter spp. on ham.

\section{Acknowledgements}

This research was supported by a grant (14162MFDS 077) from the Ministry of Food and Drug Safety in 2014.

\section{References}

1. Blackburn, C. and McClure, P. (2009) Foodborne pathogens: Hazards, risk analysis, and control. $2^{\text {nd }}$ edition. CRC Press. Cambridge.

2. Blaser, M. (1997) Epidemiologic and clinical features of Campylobacter jejuni infections. J. Infect. Dis. 176, S103-S105.

3. Borch, E. and Arinder, P. (2002) Bacteriological safety issues in red meat and ready-to-eat meat products, as well as control measures. Meat Sci. 62, 381-390.

4. CAC (Codex Alimentarius Commission) (1999) Principles and guidelines for the conduct of microbiological risk assessment. Joint FAO/WHO food standards programme. Codex Committee on Food Hygiene, 32th session, Rome, Italy, 28, June-3 July 1999.

5. Cassin, M. H., Lammerding, A. M., Todd, E. C. D., Ross, W., and Stephen McColl, R. (1998) Quantitative risk assessment for Escherichia coli O157:H7 in ground beef hamburgers. Int. J. Food Microbiol. 41, 21-44.

6. Doyle, M. P. and Erickson, M. C. (2006) Reducing the carriage of foodborne pathogens in livestock and poultry. Poult. Sci. 85, 960-973.

7. Fugimotto, S., Yuki, N., Itoch, T., and Amako, K. (1992) Specific serotype of Campylobacter jejuni associated with Guillain-Barre syndrome. J. Infect. Dis. 165, 183.

8. Ge, B., Wang, F., Sjölund-Karlsson, M., and McDermott, P. (2013) Antimicrobial resistance in Campylobacter: susceptibility testing methods and resistance trends. J. Microbiol. Methods 95, 57-67.

9. González, M., Skandamis, P., and Hanninen, M-L. (2009) A modified Weibull model for describing the survival of Campylobacter jejuni in minced chicken meat. Int. J. Food Microbiol. 136, 52-58.

10. Gormley, F., MacRae, M., Forbes, K., Ogden, I., Dallas, J., and Strachan, N. (2008) Has retail chicken played a role in the decline of human campylobacteriosis? Appl. Environ. Microbiol. 74, 383-390.

11. Haruna, M., Sasaki, Y., Murakami, M., Ikeda, A., Kusukawa, M., Tsujiyama, Y., Ito, K., Asai, T., and Yamada, Y. (2012) Pre- 
valence and antimicrobial susceptibility of Campylobacter in broiler flocks in Japan. Zoonoses Public Health 59, 241-245.

12. Heyndrickx, M., Rijpens, N., and Herman, L. (2001) Molecular detection and typing of foodborne bacterial pathogens: A review. Appl. Microbiol. 2, 193-238.

13. Jacobs-Reitsma, W. (2000) Campylobacter in the food supply. ASM Press 467-481.

14. Jung, H. (2011) Consumer survey and hazard analysis for the improvement of food hygiene and safety in purchase. M. D. thesis, Korea Univ., Seoul, Korea.

15. KREI (Korea Rural Economic Institute) (2012) Recent aspect and implication of food supply and demand. Available from: http://library.krei.re.kr/dl_images/001/035/PRN036.pdf. Accessed Aug. 26, 2015.

16. Kubota, K., Iwasaki, E., Inagaki, S., Nokubo, T., Sakurai, Y., Komatsu, M., Toyofuku, H., Kasuga, F., Angulo, F. J., and Morikawa, K. (2008) The human health burden of food borne infections caused by Campylobacter, Salmonella, and Vibrio parahaemolyticus in Miyagi prefecture, Japan. Foodborne Pathog. Dis. 5, 641-648.

17. Lammerding, A. M. and Fazil, A. (2000) Hazard identification and exposure assessment for microbial food safety risk assessment. Int. J. Food. Microbiol. 58, 147-157.

18. Lindblad, M., Lindmark, H., Lambertz, S. T., and Lindqvist, R. (2006) Microbiological baseline study of broiler chickens at Swedish slaughterhouses. J. Food Prot. 69, 2875-2882.

19. Luning, P, Devlieghere, F., and Verhe, R. (2006) Safety in the agri-food chain. Wageningen Academic Publishers. 95.

20. Mafart, P., Couvert, O., Gaillard, S., and Leguerinel, I. (2002) On calculating sterility in thermal preservation methods: application of the Weibull frequency distribution model. Int. J. Food Microbiol. 72, 107-113.

21. MFDS (Ministry of Food and Drug Safety) (2012) The study of minimum infective dose and dose-response models for foodborne pathogens. Research report.

22. MFDS (Ministry of Food and Drug Safety) (2013a) An illustrated bood to pathogenic microorganisms. Available from: http://nifds.go.kr/nifds/08_part/part01_c_b.jsp?mode=view\& article_no $=5687$. Accessed Sep. 2, 2014.

23. MFDS (Ministry of Food and Drug Safety) (2013b) Quantitative standard establishment and risk assessment of foodborne pathogens on cheese. Research report.

24. MFDS (Ministry of Food and Drug Safety) (2014) Status of foodborne illness outbreaks in Korea. Available from: http:// www.mfds.go.kr/e-stat/index.do?nMenuCode=20. Accessed Oct. 31, 2014.

25. MHW (Ministry of Health and Welfare) (2012) Korea health statistics 2012: Korea National Health and Nutrition Examination Survey (KNHNES V-3).

26. Nauta, M., Hill, A., Rosenquist, H., Brynestad, S., Fetsch, A., van der Logt, P., Fazil, A., Christensen, B., Katsma, E., Borck, B., and Havelaar, A. (2009) A comparison of risk assessments on Campylobacter in broiler meat. Int. J. Food Microbiol. 129, 107-123.

27. Nauta, M., Jacobs-Reitsma, W., and Havelaar, A. (2007) A risk assessment model for Campylobacter in broiler meat.
Risk Anal. 27, 845-861.

28. Nielsen, E. M., Fussing, V., Engberg, J., Nielsen, N. L., and Neimann, J. (2006) Most Campylobacter subtypes from sporadic infections can be found in retail poultry products and food animals. Epidemiol. Infect. 134, 758-767.

29. Notermans, S. and Teunis, P. (1996) Quantitative risk analysis and the production of microbiologically safe food: An introduction. Int. J. Food Microbiol. 30, 3-7.

30. Park, J. H. (2001) Isolation and identification of Campylobacter spp. from raw chicken carcasess in food service. J. Food Hyg. Saf. 16, 258-263.

31. Pépin, M., Russo, P., and Pardon, P. (1997) Public health hazards from small ruminant meat products in Europe. Rev. Sci. Tech. Int. Off. Epiz. 16, 415-425.

32. Pouillot, R., garin, B., Ravaonindrina, N., Diop, K., Ratsitorahina, M., Ramanantsoa, D., and Rocourt, J. (2012) A risk assessment of campylobacteriosis and salmonellosis linked to chicken meals prepared in households in Dakar, Senegal. Risk Anal. 32, 1798-1819.

33. Ross, T., Rasmussen, S., Fazil, A., Paoli, G., and Sumner, J. (2009) Quantitative risk assessment of Listeria monocytogenes in ready-to-eat meats in Australia. Int. J. Food Microbiol. 131, 128-137.

34. Sammarco, M., Ripabelli, G., Fanelli, I., Grasso, G., and Tamburro, M. (2010) Prevalence and biomolecular characterization of Campylobacter spp. isolated from retail meat. J. Food Prot. 73, 720-728.

35. Sanaa, M., Coroller, L., and Cerf, O. (2004) Risk assessment of listeriosis linked to the consumption of two soft cheeses made from raw milk: Camembert of Normandy and Brie of Meaux. Risk Anal. 24, 389-399.

36. Taremi, M., Mehdi Soltan Dallal, M., Gachkar, L., MoezArdalan, S., Zolfagharian, K., and Reza Zali, M. (2006) Prevalence and antimicrobial resistance of Campylobacter isolated from retail raw chicken and beef meat, Tehran, Iran. Int. J. Food Microbiol. 108, 401-403.

37. Teunis, P. and Havelaar, A. (2000) The beta Poisson doseresponse model is not a single-hit model. Risk Anal. 20, 513520.

38. USDA (U.S. Department of Agriculture) (2010) A focus on Campylobacter jejuni. Available from: http://fsrio.nal.usda. gov/nal_web/fsrio/fsheet.php?id=231. Accessed Nov. 5, 2013.

39. Uyttendaele, M., Baert, K., Ghafir, Y., Daube, G., De Zutter, L., Herman, L., Dierick, K., Pierard, D., Cubois, J. J., Horion, B., and Debevere, J. (2006) Quantitative risk assessment of Campylobacter spp. in poultry based meat preparations as one of the factors to support the development of risk-based microbiological criteria in Belgium. Int. J. Food Microbiol. 111, 149-163.

40. Vose, D. J. (1998) The application of quantitative risk assessment to microbial food safety. J. Food Prot. 61, 640-648.

41. Wong, T., Hollis, L., Cornelius, A., Nicol, C., Cook, R., and Hudson, J. (2007) Prevalence, numbers, and subtypes of Campylobacter jejuni and Campylobacter coli in uncooked retail meat samples. J. Food Prot. 70, 566-573.

42. Yamasaki, S., Asakura, M., Tsukamoto, T., Faruque, S., Deb, 
R., and Ramamurthy, T. (2006) Cytolethal distending toxin (CDT): Genetic diversity, structure and role in diarrheal disease. Toxin Rev. 25, 61-88.

43. Yamazaki-Matsune, W., Taguchi, M., Seto, K., Kawahara, R., Kawatsu, K., Kumeda, Y., Kitazato, M., Nukina, M., Misawa,
N., and Tsukamoto, T. (2007) Development of multiplex PCR assay for identification of Campylobacter coli, Campylobacter fetus, Campylobacter hyointestinalis subsp. hyointestinalis, Campylobacter jejuni, Campylobacter lari and Campylobacter upsaliensis. J. Med. Microbiol. 56, 1467-1473. 